UDC 616-036.22

DOI: $10.21668 /$ health.risk/2020.1.12.eng

\title{
PROCEDURE FOR ASSESSING RISKS OF AN INFECTIOUS DISEASE BEING IMPORTED AND SPREAD IN THE RF REGIONS EXEMPLIFIED WITH MEASLES IN 2018
}

\author{
I.A. Abramov ${ }^{1}$, O.P. Chernyavskaya ${ }^{2}$, A.A. Abramov ${ }^{2}$ \\ ${ }^{1}$ Centre for Strategic Planning and Management of Biomedical Health Risks, Bldg. 1, 10 Pogodinskaya Str., \\ Moscow, 119121, Russian Federation \\ ${ }^{2}$ I.M. Sechenov First Moscow State Medical University, 3 Rakhmanovskii lane, Moscow, 127994, Russian Federation
}

The authors describe a procedure for assessing risks of the measles virus being imported and spread in certain $R F$ regions; they also give results of test risk assessment in 2018 in relation to the FIFA World Cup 2018.

Risks of the virus being imported and spread in the country were assessed in accordance with a score estimation procedure aimed at assessing both internal and external risks. The procedure was developed basing on the document issued by the WHO "Rapid risk assessment for acute public health events. WHO-2012".

We detected risk factors that could make for the measles virus being imported and factors that made for secondary spread of the virus once it was imported. All the RF regions were assessed as per each factor and assigned into three categories, namely regions with high, average, and low risks of the measles virus being imported and spread. We visualized the results and presented them on maps.

As per our research results, "risk territories" are RF regions located at the state borders as well as regions where epidemiologic surveillance over measles is inefficient and there hasn't been sufficient immunization against the disease. These regions are Moscow city, Saint Petersburg, Voronezh region, Moscow region, Kaliningrad region, Samara region, Amur region, Rostov region, Sverdlovsk region, Krasnodar region, the Chechen Republic, Dagestan, Primorye, and Khabarovsk region.

Applying risk assessment in epidemiology involves developing such a technique for examining and forecasting an epidemiologic situation which will allow determining influence exerted on them by risk factors. This procedure enables ranking problems as per their significance and minimizing or eliminating possible risks.

Key words: risk assessment, epidemiology, measles, risk-oriented surveillance, infectious diseases being imported into a country, aerogenic contagion, FIFA World Cup, tourism.

Social and economic structure of the contemporary world society involves growing inter-continental and inter-state migration as well as intensifying international relations; it exerts significant influence on spread of communicable diseases from country to country [1].

Mass international events play a substantial role in tourist flows becoming more and more intense. Such events are trade fairs, congresses, festivals, exhibitions, and sport events and they usually involve short-term but mass inflow of participants or sport fans from a great number of countries including those that are endemic as per extremely dangerous quarantine infections. Therefore, it is truly vital to promptly assess epidemiologic risks in the contemporary world with life in it becoming faster and faster.

Respiratory viruses occupy the most significant place in human infectious pathology as they tend to cause mass communicable diseases. Wide spread of acute viral respiratory infections makes it necessary to develop rapid and efficient procedures for predicting new mass contagions in order to improve epidemiologic surveillance and accelerate elimination of viral infections.

(C) Abramov I.A., Chernyavskaya O.P., Abramov A.A., 2020

Ivan A. Abramov - Junior researcher (e-mail: abramovMGMU@yandex.ru; tel.: +7 (967) 167-66-04; ORCID: https://orcid.org/0000-0002-7433-7728).

OI ga P. Chernyavskaya - Candidate of Medical Sciences, Associate Professor at the Department for Epidemiology and Evidence Based Medicine of the Medical and Prevention Faculty (e-mail: zavepid@mail.ru; tel.: +7 (905) 724-89-19; ORCID: http://orcid.org/0000-0002-9981-3487).

Aleksei A. Abramov - Student (e-mail: leksey190699@bk.ru; tel.: +7 (909) 996-41-74; ORCID: http://orcid. org/0000-0003-3893-4434). 
Measles is one of the most contagious diseases among known communicable ones. Almost $100 \%$ people are susceptible to this infection and vaccination remains the most efficient way to fight against measles. People who were not vaccinated remain susceptible to measles during their lifetime and can catch it at any age. As per data provided by the WHO, the situation with measles is unfavorable in many countries all over the world [2].

The WHO European Office felt inspired with successes achieved in eliminating poliomyelitis; its experts developed and implemented a strategic program aimed at preventing measles and congenital rubella in the Europe in 2002.

The basic goal of the program was to eliminate measles and to prevent congenital rubella by $2010^{1}$ [3-4]. Prior to these initiatives aimed at eliminating measles and rubella, 562,000 children died annually all over the world due to complications caused by measles.

As per data provided by the $\mathrm{WHO}$, as more and more people got vaccinated, an apparent descending trend appeared in morbidity with measles in different regions in the world. Predicted long-term morbidity with measles was so low that it allowed believing measles would be eliminated completely in 2015. Despite significant successes achieved due to initiatives aimed at eliminating measles and rubella, 115,000 children, mostly those younger than 5, annually die from these diseases all over the world. It is approximately 314 people per day or 13 deaths per hour.

Initially, experts planned to eliminate measles in 2010-2015; but now elimination seems to move into distant future. Morbidity with measles registered in Europe in 2016-2018 was considered by the WHO as epidemic. Thus, in 2018 approximately 60 thousand measles cases were registered in European countries. In 2018 high morbidity was registered in Ukraine $(1,209.25$ per 1 million people), Serbia (579.3 per 1 million people), Albania (499.6 per 1 million people), Georgia (563.8 per 1 million people),
Monte Negro (322.6 per 1 million people), and Greece (196.8 per 1 million people) [5-8]. $43 \%$ patients were adults older than 20 . Measles epidemic process in Russia also became more active. Morbidity with measles grew by 3.5 times in 2018 against 2017 and amounted to 17.3 per 1 million people (4.9 in 2017). 2,538 measles cases were registered. Low protection against the infection among adult population is the basic reason for this growth. Over recent years European countries have faced certain difficulties including a reduction in scales of scheduled immunization, stably low immunization among marginal population groups, troubles with vaccine supplies, and inefficient performance by epidemiologic surveillance authorities.

Countries take complex measures aimed at eliminating existing outbreaks and preventing new ones. Such measures include more intense communication about the problem with the society; immunization among medical personnel and other adult population groups who run high risks of the disease; elimination of any obstacles preventing a person form being vaccinated; better planning and material support for vaccine supplies [9].

In the present work the authors first selected and then analyzed criteria for assessing external and internal risks of measles viruses being imported onto the RF territory.

Our research goal was to work out a procedure for a score estimate of risks that a communicable disease would be imported and then spread in the country; the next goal was to assess risks of measles virus being imported and spread in certain RF regions.

\section{The following tasks were to be solved:}

- to work out criteria for assessing external and internal risks that an epidemiologic situation as per measles would deteriorate;

- to assess external risks that measles virus would be imported onto the RF territory, in particular, migration flows and communications with countries where the situation with measles is adverse;

\footnotetext{
1 "The Program "Elimination of measles and rubella in the Russian Federation" (2016-2020)" (approved by Rospotrebnadzor on December 28, 2015, The RF Public Healthcare Ministry on December 31, 2015). Laws, codes and legal acts of the Russian Federation. Available at: https://legalacts.ru/doc/programma-eliminatsija-kori-i-krasnukhi-v-rossiiskoi-federatsii-2016/ (10.06.2019).
} 
- to assess internal epidemiologic risks that measles virus would spread, in particular, quality of epidemiologic surveillance over measles and number of people vaccinated against the disease; to reveal "risk territories" (RF regions that were the most susceptible to risks of measles virus being imported and spread across them);

- to develop a draft procedure for score estimate of risks that measles virus would be imported and spread.

Data and methods. We took data from the Federal Statistic Service on population migration; data from the Statistic Form No. 2 "Data on infectious and parasitic diseases" over 2015-2018; data from the Statistic Form No. 6 "Data on children and adult groups vaccinated against communicable diseases" over 2015-2018; data on a number of border checkpoints in RF regions where people can cross the RF State Border; data of "The national vaccination schedule" on mass events with international participation.

We applied a procedure for score estimate of external and internal risks. When selecting criteria and working out our risk assessment procedure, we followed the Guide entitled "Rapid risk assessment of acute public health events" developed by the World Health Organization (WHO) in 2012 [9]. A direct choice on these or those assessment criteria depended on properties of data that characterize an epidemic process and risk factors in their quantitative equivalent; such data were to be used in operative risk assessment and therefore they should be available, reliable and easy to obtain in due time. Digital values that characterized factors of a communicable diseases import and spread were taken from state observations and other open data sources. Each risk factor was given a score estimate, from 0 (minimum) to 2 (maximum) depending on how active it was. We chose this exact factor gradation based on epidemically significant values in order to make the model simpler and calculations more rapid. A similar procedure for score estimate of parameters was used by several researchers to quantitatively assess potential epidemiologic threats; in particular, when mass sport events took place [11-13]. Each RF region was assessed as per all the criteria for assess- ing external and internal risks. Then those scores were summed up and ranked as per their value; after that we calculated sigma (standard deviation) and a rank was assigned to each region depending on its value. We created a "calculator" based on Microsoft Excel for scores being automatically distributed as per input data and preset criteria. Having performed all the necessary calculations, we divided all the RF regions into three categories: territories with high, average, and low risks of measles virus being imported and spread; we also visualized our results on maps with specific GIS software (Map Info 16 Pro).

Results and discussion. Risk assessment is a systematic process of collecting, analyzing, and documenting data in order to determine levels of examined risks. It gives grounds for efficient measures aimed at reducing and eliminating consequences of events that imposed direct threats for population health.

In order to assess risks related to measles virus being imported and spread across the RF territory according to the procedures developed by the $\mathrm{WHO}$, we determined internal and external risk factors that could make for deterioration of the epidemiologic situation in the country (Tables 1 and 2). Depending on values of these factors, all the RF regions were to be assigned into three categories:

- low risk territories (the lowest probability that the epidemiologic situation would deteriorate in comparison with other regions in the country);

- average risk territories (a risk that the epidemiologic situation might deteriorate is equal to average country level or differs from it insignificantly);

- high risk territories or "risk territories"; they are territorial units (geographic or administrative ones) where morbidity and/or its consequences are higher or a certain epidemiologic phenomenon is more prevailing than on other comparable territories [14]).

International migration is a primary criterion of external risks. According to official Rosstat reports, annually people from countries where the situation with measles is adverse come to the Russian Federation (Table 3). These data don't include illegal migration and 
transit passengers from these countries. At present world airlines annually transport more than 2 billion passengers and it creates greater opportunities for rapid spread of communicable diseases and their carriers. Contemporary tourism is one of the largest and most rapidly developing spheres in the world economy due to intensifying globalization and development of international transportations [15].
As per data taken from Rosturism report entitled "Selected statistic data calculated according to the official statistic methodology for assessing a number of in and out tourist trips", annually more than 24 million foreign citizens come to the Russian Federation as tourists. In 2017 more than 39 million Russian citizens made tourist trips abroad and it was by $25 \%$ higher than in 2016.

\section{Criteria for external risk assessment}

\begin{tabular}{|l|l|}
\hline $\begin{array}{l}\text { An international air border checkpoint to cross } \\
\text { the RF State Border }\end{array}$ & $\begin{array}{l}\text { l scores, absent; 1 score, cargos and goods movement; } \\
2 \text { scores, people movement. }\end{array}$ \\
\hline $\begin{array}{l}\text { An international motorway border checkpoint } \\
\text { to cross the RF State Border }\end{array}$ & $\begin{array}{l}0 \text { scores, absent; 1 score, cargos and goods movement; } \\
2 \text { scores, people movement. }\end{array}$ \\
\hline $\begin{array}{l}\text { An international railway border checkpoint to } \\
\text { cross the RF State Border }\end{array}$ & $\begin{array}{l}0 \text { scores, absent; 1 score, cargos and goods movement; } \\
2 \text { scores, people movement. }\end{array}$ \\
\hline $\begin{array}{l}\text { An international marine border checkpoint to } \\
\text { cross the RF State Border }\end{array}$ & $\begin{array}{l}0 \text { scores, absent; } 1 \text { score, cargos and goods movement; } \\
2 \text { scores, people movement. }\end{array}$ \\
\hline $\begin{array}{l}\text { An international river border checkpoint to } \\
\text { cross the RF State Border }\end{array}$ & $\begin{array}{l}0 \text { scores, absent; 1 score, cargos and goods movement; } \\
2 \text { scores, people movement. }\end{array}$ \\
\hline Long-distance railways & $\begin{array}{l}0 \text { scores, absent; 1 score, passenger transportation on } \\
\text { the RF territory; } 2 \text { scores, international passenger } \\
\text { transportations. }\end{array}$ \\
\hline Migration & $\begin{array}{l}0 \text { scores, migration is lower than on average in the } \\
\text { country; } 1 \text { score, migration is equal to that on average } \\
\text { in the country; } 2 \text { scores, migration is higher than on } \\
\text { average in the country. }\end{array}$ \\
\hline $\begin{array}{l}\text { Mass events with international participation to } \\
\text { take place in a region }\end{array}$ & $\begin{array}{l}0 \text { scores, not scheduled; } 1 \text { score, one or more such } \\
\text { events are scheduled }\end{array}$ \\
\hline
\end{tabular}

Criteria for internal risk assessment

\begin{tabular}{|l|l|}
\hline Average morbidity with measles over & $\begin{array}{l}\text { scores, morbidity is lower than 1 per 1 million peo- } \\
\text { ple; 1 score, morbidity is higher than 1 but lower than } \\
5 \text { per 1 million people; 2 scores, morbidity is higher } \\
\text { than 5 per 1 million people }\end{array}$ \\
\hline Measles outbreaks in a region over the last year & $\begin{array}{l}\text { 0 scores, no measles outbreaks; 1 score, one or more } \\
\text { measles outbreaks }\end{array}$ \\
\hline $\begin{array}{l}\text { Number of people vaccinated against measles } \\
\text { in a region }\end{array}$ & $\begin{array}{l}0 \text { scores, 97\% or more people vaccinated; 1score, } \\
95-97 \% \text { people vaccinated; 2 scores, less than 95\% } \\
\text { people vaccinated }\end{array}$ \\
\hline
\end{tabular}

Territories (districts) in a region where less than 0 scores, no such districts; 1 score, one such district in $95 \%$ population are vaccinated against measles a region; 2 scores, more than 1 such district in a region

0 scores, fewer than 10,000 infants in a region;

Number of infants younger than 1 year

1 score, more than 10,000 , but fewer than on average per 100 thousand people over the last year

in the country $(20,714)$;

2 scores, more infants than on average in the country $(20,714)$

Deaths from measles over the last five years

0 scores, no deaths; 1 scores, there are deaths from measles 
Table 3

Number of people who came to the Russian Federation from countries that are endemic and adverse as per measles virus over 2010-2017

\begin{tabular}{|l|c|c|c|c|c|c|c|c|}
\hline & 2010 & 2011 & 2012 & 2013 & 2014 & 2015 & 2016 & 2017 \\
\hline Ukraine & 27,508 & 43,586 & 49,411 & 55,037 & 126,819 & 194,180 & 178,274 & 150,182 \\
\hline France & 150 & 322 & 326 & 352 & 351 & 360 & 303 & 346 \\
\hline Greece & 298 & 614 & 835 & 995 & 694 & 557 & 450 & 419 \\
\hline Germany & 2,621 & 4,520 & 4,239 & 4,166 & 3,743 & 3,976 & 4,153 & 3,704 \\
\hline Bulgaria & 214 & 371 & 353 & 419 & 346 & 392 & 293 & 238 \\
\hline Czechia & 112 & 157 & 193 & 192 & 160 & 180 & 148 & 151 \\
\hline Spain & 140 & 201 & 253 & 364 & 303 & 279 & 218 & 227 \\
\hline Serbia & 159 & 600 & 576 & 943 & 860 & 682 & 589 & 769 \\
\hline India & 110 & 1,390 & 1,068 & 1,451 & 1,850 & 2,894 & 4,768 & 5,622 \\
\hline Tajikistan & 18,188 & 35,087 & 41,674 & 51,011 & 54,658 & 47,638 & 52,676 & 63,467 \\
\hline Kirgizia & 20,901 & 41,562 & 34,597 & 30,388 & 28,543 & 26,045 & 28,202 & 41,165 \\
\hline Turkmenistan & 2,283 & 4,524 & 5,442 & 5,986 & 6,038 & 6,539 & 7,242 & 8,734 \\
\hline The United Kingdom & 125 & 166 & 182 & 221 & 185 & 273 & 226 & 375 \\
\hline
\end{tabular}

Also, we took another external risk criterion and it was activity of international migration in a region and reasons for its occurrence. First of all, we considered its possible pathways or international border checkpoints where the RF State Border could be crossed. Then, we considered mass events with international participation that took place in a region.

As per results obtained via score estimate, all the regions were ranked and it allowed revealing regions with the highest risks that mea- sles virus could be imported there in 2018. They were Kaliningrad region (6 scores); Krasnodar region (6 scores); Moscow city (5 scores); Saint Petersburg (5 scores); Rostov region (5 scores); Dagestan (5 scores); Primorye (5 scores); Moscow region (4 scores); Khabarovsk region (4 scores); Crimea (4 scores). 4 scores were a threshold for assigning a region into high external risk category.

For better visualization, analysis results are given on a map in Figure 1.

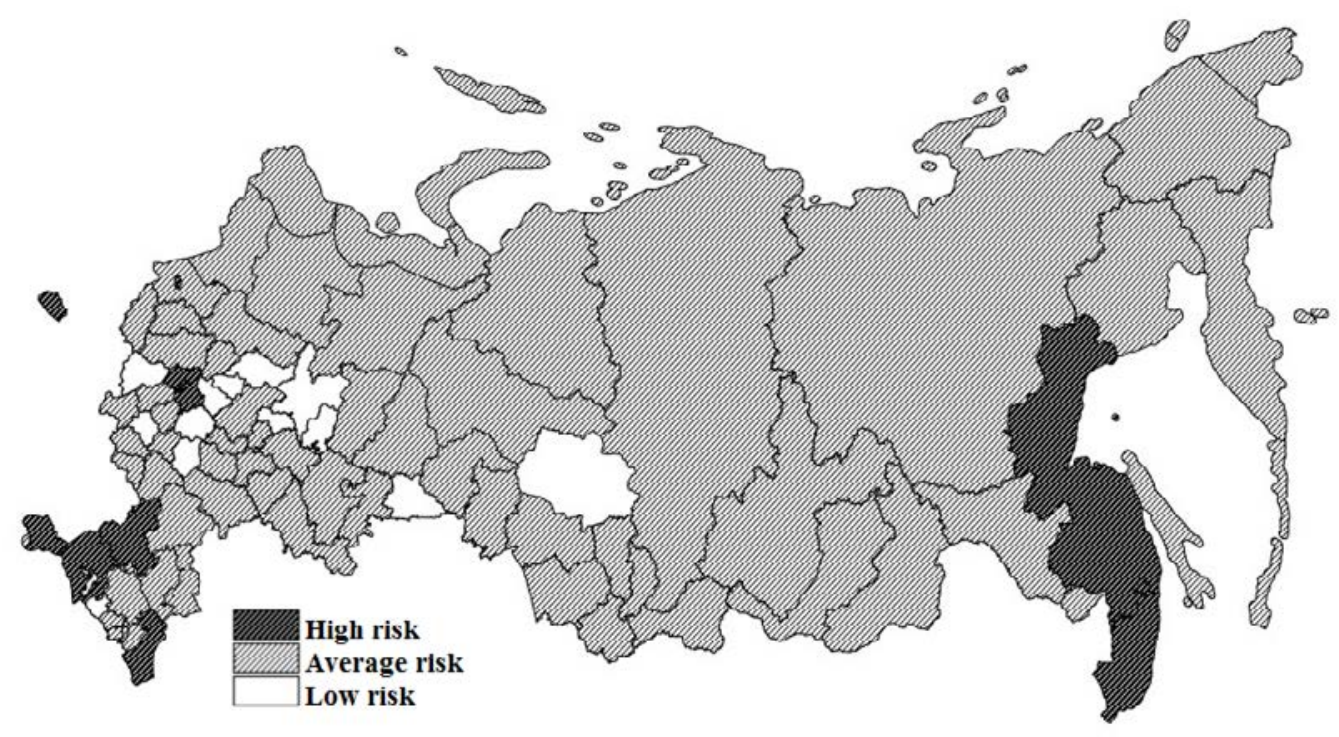

Figure 1. RF regions distributed as per external risks of measles virus import in 2018 
GIS technologies are now a significant element in epidemiologic surveillance. Medicalgeographic maps are a relatively new type of subject maps. Drawing up such a map requires specific knowledge and approaches [16]. Bearing in mind, that a map is always a better visual than a table, we applied a GIS software program Map Info Pro 16 to create a specific cartographic model as per results of our calculations; the model gave a tentative picture of an actual situation.

When analyzing possible outcomes resulting from import of communicable diseases, it is necessary to differentially assess probable secondary spread of a disease and potential threat that it could persist in new conditions as probability of such outcomes is determined by different sets of factors [17].

We selected several internal risk factors that could make for a measles outbreak; they were criteria describing quality of epidemiologic surveillance in each specific region:

- average morbidity with measles per 1 million people over 2009-2018; measles outbreaks in the last year;

- a share of people vaccinated against measles in a region;

- districts within a region where less than $95 \%$ people were vaccinated against measles;

- number of infants younger than 1 year per 100 thousand people.

Sanitary-epidemiologic authorities can influence external risks only indirectly; but as for internals ones, obviously quality of sanitary-epidemiologic surveillance is a direct responsibility of sanitary-epidemiologic authorities and public healthcare organizations in a $R F$ region.

Certain RF regions ran the highest risks of measles outbreaks in case the virus was imported into them in 2018. They were Chechen Republic (6 scores); Moscow city (5 scores); Dagestan (5 scores); Ingushetia (5 scores); Kabardino-Balkaria (5 scores); KarachaiCherkess (5 scores); Yakutia (5 scores); Voronezh region (4 scores); Kaluga region (4 scores); Moscow region (4 scores); Krasnodar region (4 scores); Astrakhan region (4 scores); Rostov region (4 scores); Samara region (4 scores); Sverdlovsk region (4 scores); Tomsk region (4 scores); Amur region (4 scores) (Figure 2). 4 scores were a threshold for assigning a region into high internal risk category.

Then we combined both groups of criteria, determined combined risks, and ranked territories as per them (Figure 3 ).

"Risk territories" in terms of measles virus import and transfer in 2018 were Moscow city (10 scores); Krasnodar region (10 scores); Dagestan region (10 scores); Rostov region (9 scores); Moscow region (8 scores); Kaliningrad region (8 scores); Voronezh region (7 scores); Saint Petersburg (7 scores); Chechen Republic ( 7 scores); Samara region

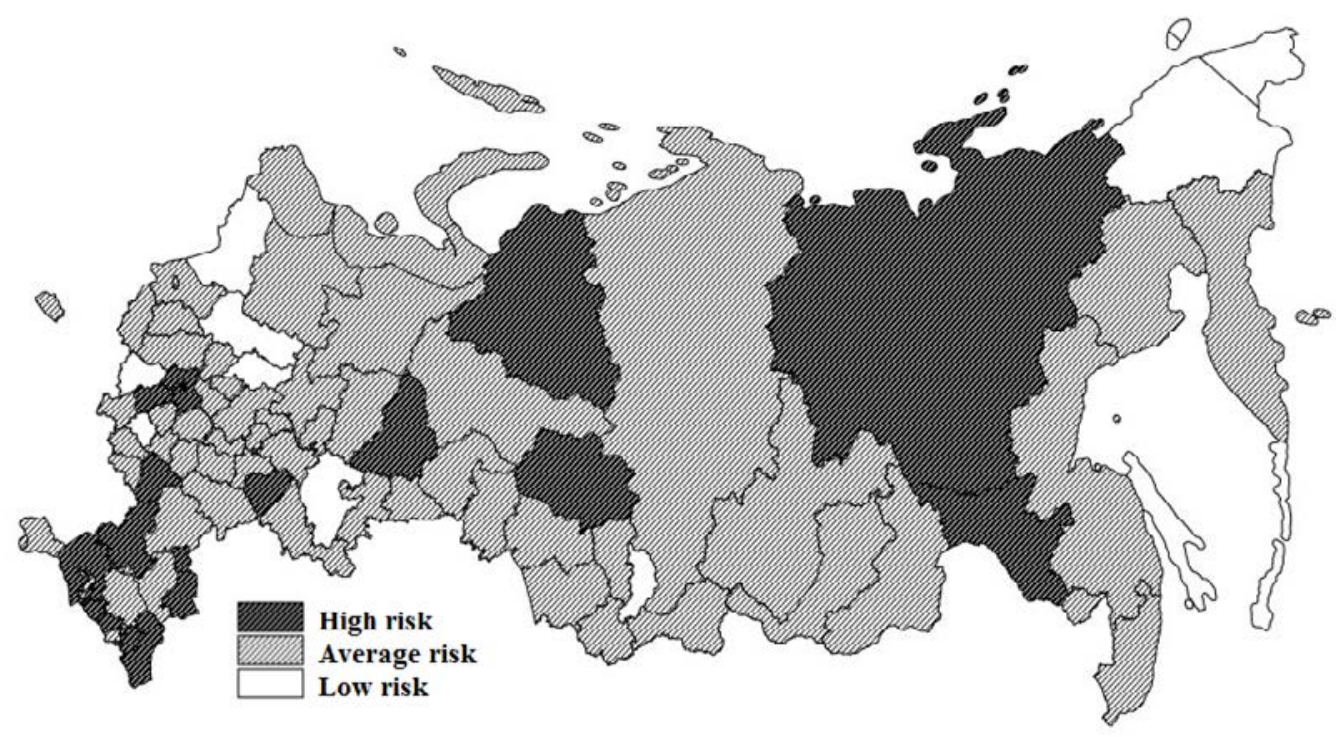

Figure 2. RF regions distributed as per internal risks of measles virus spread in 2018 


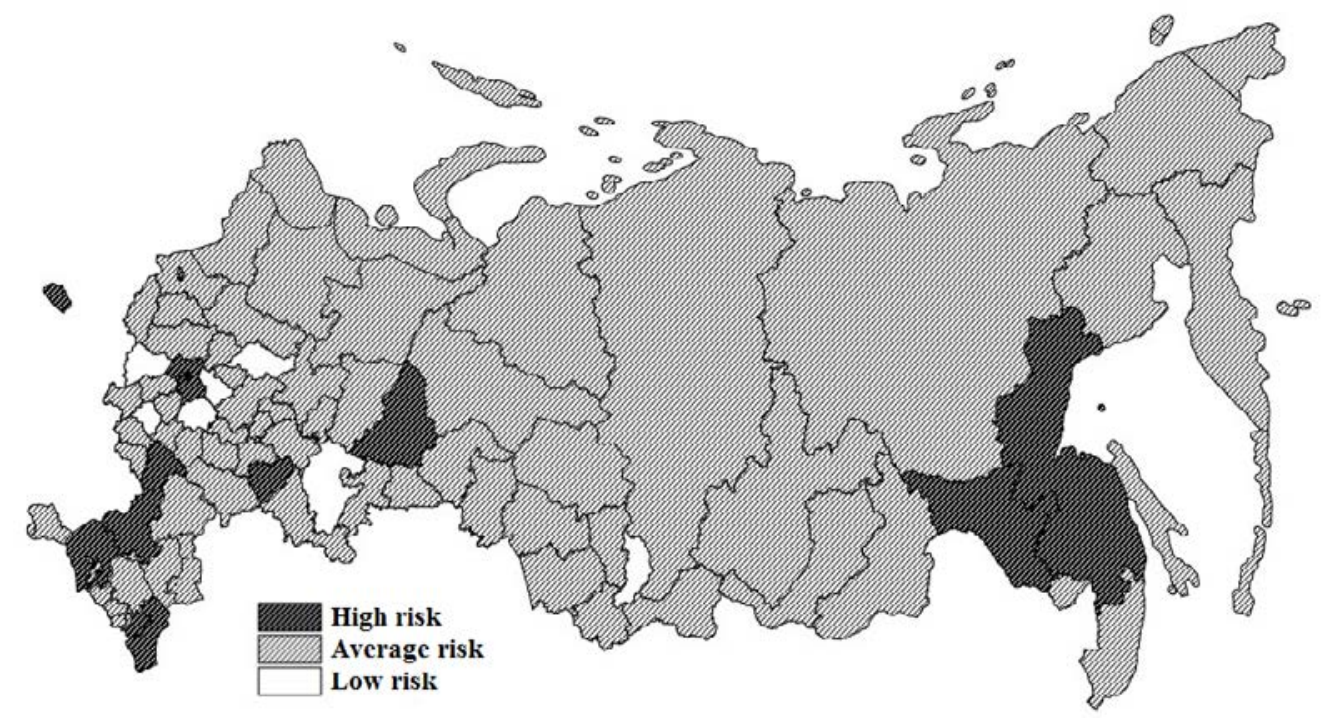

Figure 3. RF regions distributed as per external and internal risks of measles virus import and spread in 2018

(7 scores); Sverdlovsk region (7 scores); Khabarovsk region ( 7 scores); Amur region ( 7 scores). 7 scores were a threshold value to assign a region into "risk territory" category.

We should note that Moscow city is the only RF region where both external and internal risks are high. Obviously it is due to most international communications being concentrated in the city.

Therefore, our research allowed us to reveal regions with high, average, and low risks basing on score estimates given for external and internal risk parameters. As expected, border regions in the country turned out to be risk territories with both external and internal risks being high; the category also included regions where epidemiologic surveillance over measles was inefficient and not enough people were vaccinated against the disease.

Having analyzed morbidity with measles in RF regions in 2018 (data taken from the Statistic Form No. 2 "Data on infectious and parasitic diseases"), we revealed regions where morbidity was higher than 5 cases per 1 million people (Table 4).

Then, we assessed whether the model was relevant. To do that, we compared predictions and actual morbidity on the assumption that if actual figures differ from risk levels (being lower), it can't be interpreted as errors in results obtained with the prediction model. Coincidence amounted to $68 \%$.
Also, when comparing predictions with actual figures, we revealed three RF regions where morbidity differed drastically from their risk group. They were Kaluga region, Kostroma region, and Bashkortostan. Morbidity was unexplainably high in these three regions bearing in mind criteria obtained for them via assessing risks of the disease spread in case measles virus was imported into them and data obtained via statistic observations. It can be probably due to some unaccounted factors or a dramatic deterioration of epidemiologic surveillance over measles virus in 2018 in these regions. It can also indirectly imply that statistic data are collected and present rather improperly in these $\mathrm{RF}$ regions.

It was also important to analyze morbidity in 11 regions (data taken from the Statistic Form No. 2 "Data on infectious and parasitic diseases") where events of FIFA World Cup 2018 took place, namely:

- Moscow, 926 registered measles cases;

- Krasnodar region, 66 registered measles cases;

- Saint Petersburg, 54 registered measles cases;

- Rostov region, 49 registered measles cases;

- Samara region, 22 registered measles cases;

- Tatarstan region, 12 registered measles cases;

- Sverdlovsk region, 8 registered measles cases; 
Table 4

Regions where morbidity with measles was higher than 5 cases per 1 million people in 2018

\begin{tabular}{|l|c|}
\hline \multicolumn{1}{|c|}{ RF region } & $\begin{array}{c}\text { Morbidity } \\
\text { per 1 million } \\
\text { people }\end{array}$ \\
\hline Dagestan & 89.42 \\
\hline Kaluga region & 85.85 \\
\hline Moscow city & 74.42 \\
\hline Moscow region & 53.59 \\
\hline Karelia & 46.42 \\
\hline Adygei & 39.70 \\
\hline North Ossetia & 34.16 \\
\hline Ingushetia & 33.04 \\
\hline Chechen Republic & 28.75 \\
\hline Stavropol region & 26.76 \\
\hline Transbaikalia & 25.10 \\
\hline Vladimir region & 24.57 \\
\hline Tambov region & 24.11 \\
\hline Novosibirsk region & 19.40 \\
\hline Crimea & 19.34 \\
\hline Khanty-Mansi Autonomous Area & 15.15 \\
\hline Krasnodar regiom & 11.81 \\
\hline
\end{tabular}

\begin{tabular}{|l|c|}
\hline \multicolumn{1}{|c|}{ RF region } & $\begin{array}{c}\text { Morbidity } \\
\text { per 1 million } \\
\text { people }\end{array}$ \\
\hline Leningrad region & 11.65 \\
\hline Rostov region & 11.60 \\
\hline Kalmykia & 10.85 \\
\hline Kostroma region & 10.84 \\
\hline Astrakhan region & 10.80 \\
\hline Tula region & 10.70 \\
\hline Saint Petersburg & 10.16 \\
\hline Yamal-Nenets Autonomous Area & 9.31 \\
\hline Bashkortostan & 8.61 \\
\hline Karachai-Cherkess & 8.58 \\
\hline Penza region & 8.23 \\
\hline Primorye & 7.82 \\
\hline Sevastopol & 6.93 \\
\hline Magadan region & 6.90 \\
\hline Samara region & 6.88 \\
\hline Kamchatka & 6.35 \\
\hline Khabarovsk & 5.26 \\
\hline
\end{tabular}

- Volgograd region, 6 registered measles cases;

- Nizhniy Novgorod region, 4 registered measles cases;

- Kaliningrad region, 2 registered measles cases;

- Mordovia, 1 registered measles case.

Seven out of these regions were "risk territories" as per measles virus according to the prediction; four were assigned into "average risk" category in terms of measles virus being imported and spread across them. Undoubtedly, the FIFA World Cup made a significant contribution into an increase in morbidity with measles in the regions but it was higher than 5 cases per 1 million people in only five of them (Moscow city, Krasnodar region, Saint Petersburg, Rostov region, and Samara region). Still we should point out that, apart from the World Cup, other risk factors were rather high in those regions. Therefore, it can indirectly imply that epidemiologic surveillance over measles virus was quite satisfactory in those regions during a great mass event with international participation.

Authenticity of the risk assessment was determined according to the document devel-

oped by the WHO and entitled "Rapid risk assessment of acute public health events. WHO 2012". It is very important to document level of confidence in an assessment performed by an assessment group as well as reasons for not making an assessment more precise.

Precision of any assessment depends on applied data being authentic, complete and qualitative as well as on correctness of basic assumptions regarding hazards, exposure and context of an event.

Level of confidence in results obtained by an assessment group is directly proportionate to quantity of actual data on hazards, exposure, and context of an event.

We can state that the level of confidence in our assessment and its results is high due to use of official statistic data, documents, and statistic reports that were issued basing on data obtained by authorities responsible for epidemiologic surveillance over measles virus in the Russian Federation.

Our procedure was developed on the basis of the WHO document entitled "Rapid risk assessment of acute public health events"; the document was originally developed to assess 
risks related to spread of poliomyelitis across the European countries. The procedure is aimed at rapid operating risk assessment and prediction how a situation will develop in a year following the examined one. This procedure for calculating risks that a communicable disease will be imported and spread in RF regions has some similarities with analogue procedures developed by Russian authors but it also has some differences [18-20]. A difference is a complex approach to analyzing social, economic, demographic, and epidemiologic risk factors. Another difference is that our examination involved assessing risks related to import and spread of an infection that could be managed via immune prophylaxis. Most previous research accomplished by Russian scientists focused on mapping and revealing "risk territories" regarding natural foci infections and parasitic diseases that are endemic in their essence [16]. The procedure has certain drawbacks as it assigns RF regions only into three categories, with high, average and low risks; it also has a rather generalized nature as it is designed for an operating assessment and developing preventive activities as the federal level.

The results which we obtained can be applied as independent data in activities performed by Rospotrebnadzor authorities and aimed at developing targeted plans of preventive measures in administrative districts assigned into "risky territories" category. Such activities can be related to creating stocks of anti-measles vaccine and medications for treating the infection; making laboratory support ready for clinical ex- aminations; organizing workshops on epidemiology and clinical issues regarding measles in order to increase epidemiologic suspicion among primary medical personnel.

It is also advisable and highly desirable to add various criteria to the procedure and apply it to perform rapid assessment of other epidemic (biological) risks as it was shown on the example of wild poliomyelitis virus.

The next stage in developing this prediction model will be an attempt to assess risks of measles virus as well as other communicable diseases being imported and spread in 2019 and to create an online service for rapid calculation and public use of this analytical model.

Conclusion. Significant migration flows and insufficient vaccination against measles both in Russia and abroad create a threat that measles virus can be imported, spread across the RF territory and then persist in the country.

When a risk assessment is applied in epidemiology, it involves developing a procedure for examining and predicting an epidemiologic situation that will allow determining influence exerted on it by risk factors. Such a procedure provides an opportunity to rank problems as per their significance and minimize or even eliminate risks completely. In other words, to manage a risk means to monitor and assess it and implement systems designed for managing risks.

Funding. The research was not granted any financial support.

Conflict of interests. The authors declare there is no any conflict of interests.

\section{References}

1. Cherkasskii B.L., Sergiev V.P., Ladnyi I.D. Epidemiologicheskie aspekty mezhdunarodnoi migratsii naseleniya [Epidemiologic aspects related to international migration of population]. Moscow, Meditsina Publ., 1984, 208 p. (in Russian).

2. PonezhevaZh.B., Arakelyan A.K., Kozlova M.S., Vdovina E.T. Measles in adults. Epidemiologiya i infektsionnye bolezni. Aktual'nye voprosy, 2018, no. 2, pp. 50-55 (in Russian).

3. Eliminating measles and rubella and preventing congenital rubella infection: WHO European Region strategic plan 2005-2010. Copenhagen, WHO, Regional Office for Europe, 2005, 37 p. (in Russian).

4. O situatsii s zabolevaemost'yu kor'yu v Rossii i zarubezhnykh stranakh [On morbidity with measles in Russia and abroad]. Available at: http://www.rospotrebnadzor.ru/about/info/news/news_details.php? ELEMENT_ID=11283 (28.07.2019) (in Russian).

5. Georgakopoulou T., Horefti E., Vernardaki A., Pogka V., Gkolfinopoulou K., Triantafyllou E., Tsiodras S., Theodoridou M. [et al.]. Ongoing measles outbreak in Greece related to the recent European-wide epidemic. Epidemiol. Infect., 2018, vol. 146, no. 13, pp. 1692-1698. DOI: 10.1017/S0950268818002170 
6. Barrett P., Cotter S., Ryan F., Connell J., Cronin A., Ward M., Fitzgerald R., Lynch C., Margiotta T. A national measles outbreak in Ireland linked to a single imported case April to September 2016. Euro. Surveill., 2018, no. 31, 9 p. DOI: 10.2807/1560-7917.ES.2018.23.31.1700655

7. Bernadou A., Astrugue C., Méchain M., Le Galliard V., Verdun-Esquer C., Dupuy F., Dina J., Aït-Belghiti F., Antona D., Vandentorren S.Measles outbreak linked to insufficient vaccination coverage in Nouvelle-Aquitaine Region France October 2017 to July 2018. Euro. Surveill., 2018, no. 30, pp. 1-5. DOI: $10.2807 / 1560-7917 . E S .2018 .23 .30 .1800373$

8. Europe observes a 4-fold increase in measles cases in 2017 compared to previous year. Copenhagen, World Health Organization, 2018. Available at: http://www.euro.who.int/en/media-centre/sections/ press-releases/2018/europe-observes-a-4-fold-increase-in-measles-cases-in-2017-compared-to-previous-year (28.07.2019) (in Russian).

9. Rapid risk assessment of acute public health events. World Health Organization, 2012, $44 \mathrm{p}$.

10. Onishchenko G.G., Patyashina M.A., Udovichenko S.K., Toporkov A.V., Kouklev E.V., Toporkov V.P., Kutyrev V.V. Quantitative Assessment of Potential Epidemic Hazard of Mass Events with International Participation and Methodology Approbation in the Context of Universiade-2013. Problemy osoboopasnykh infektsii, 2015, no. 2, pp. 5-8 (in Russian).

11. PopovaA.Yu., Balakhonov S.V., Goryaev D.V., Dmitrieva G.M., Filatova S.A., Sharakshanov M.B., Vishnyakov V.A., Mironova L.V. [et al.]. Estimation of risks of importations and distribution of dangerous infectious diseases during the xxix winter Universiade-2019 in Krasnoyarsk. Zdorov'e naseleniya $i$ sreda obitaniya, 2018, vol. 6, no. 303, pp. 4-11 (in Russian).

12. Kutyrev V.V., Karnaukhov I.G., Goncharov S.F., Prosin V.I., Suranova T.G. Ensuring Sanitary and Epidemiological Well-Being of the Population When Conducting Mass Activities as One of the Components of the Biological Security System. Meditsina katastrof, 2018, vol. 103, no. 3, pp. 42-46 (in Russian).

13. Shugaeva S.N., Savilov E.D. Risk in Epidemiology: Terminology, main Definitions and Systematization of Concepts. Epidemiologiya $i$ vaktsinoprofilaktika, 2017, vol. 6, no. 97, pp. 73-78 (in Russian).

14. Briko N.I. In the United States Summarized Influenza Vaccination Epidemiological Season 2012-2013. Epidemiologiya i vaktsinoprofilaktika, 2013, vol. 6, no. 73, pp. 4-10 (in Russian).

15. Morozov aL.F., Sergiev V.P., Filatov N.N. Geoinformatsionnye tekhnologii v profilaktike infektsionnykh I parazitarnykh boleznei [Geoinformation technologies in infectious and parasitic diseases prevention]. Moscow, Nauka Publ., 2017, 191 p. (in Russian).

16. Cherkasskii B.L. Risk v epidemiologii [Risk in epidemiology]. Moscow, Prakticheskaya Meditsina Publ., 2007, 480 p. (in Russian).

17. Vodop'yanov A.S., Pichurina N.L., Titova S.V., RyzhkovYu.V., Vodop'yanov S.O., Oleinikov I.P. Avtomatizirovannaya onlain sistema otsenki riska zavoza infektsionnykh zabolevanii na territoriyu Rossii [Automated online-system for assessing risks of infectious diseases being imported onto the territory of Russia]. Infektsiya i immunitet, 2017, no. S, pp. 115-116 (in Russian).

18. Noskov A.K., Vishnyakov V.A., Lapa S.E., Zaitseva T.A., Dampilova I.G., Popova A.V. Sanitary protection of the territory of Russian Federation. Report 2. The differentiation of the territory of a region of Russian Federation for risk of diseases dangerous for people. Byulleten' Vostochno-Sibirskogo nauchnogo tsentra sibirskogo otdeleniya rossiiskoi akademii meditsinskikh nauk, 2013, vol. 1, № 89, pp. 140-144 (in Russian).

19. Ivanova A.V., Safronov V.A., Stepanov E.G., Mochalkin P.A., Popov N.V. Detection of Territories of High Risk HFRS Exposure in the Republic of Bashkortostan, Applying GIS-Technologies. Problemy osoboopasnykh infektsii, 2016, no. 2, pp. 40-44 (in Russian).

20. Chernyavskaya O.P., Briko N.I., Abramov I.A., Mandzhiev O.B. Assessment of Risk of Importation and Spread of Wild Polio Virus in Territory of Russian Federation Subjects. Meditsina katastrof, 2019, vol. 107, no. 3, pp. 48-52 (in Russian).

Abramov I.A., Chernyavskaya O.P., Abramov A.A. Procedure for assessing risks of an infectious disease being imported and spread in the RF regions exemplified with measles in 2018. Health Risk Analysis, 2020, no. 1, pp. 108-117. DOI: 10.21668/health.risk/2020.1.12.eng

Received: 30.10 .2019

Accepted: 03.02 .2020

Published: 30.03 .2020 